\title{
Trends and Issues in Adult Education Evaluation: The Latvia Case
}

\author{
Gilberto Marzano, Velta Lubkina, Svetlana Usca \\ Rezekne University of Applied Sciences, Rezekne, Latvia
}

\author{
Tamara Pigozne \\ University of Latvia, Riga, Latvia
}

\begin{abstract}
This article presents the results of an investigation conducted in Latvia within the scope of the European Union's (EU) Evaluation for the Professional Development of Adult Education Staff (EduEval) project concerning the evaluation of adult education. The investigation started in 2014, with a methodology based on the review of current literature, analysis of statistic data and official documents, Web analysis, and a sampling based on semi-structured interviews. The results of this research show that in Latvia, adult education is generally connected to the business sector, and is considered a means by which to acquire useful skills for career progression or for retaining employment. The majority of adult educators acting within non-formal learning environments are self-taught professionals, and there are no officially consolidated policies for the evaluation of adult education. However, Latvian educators and researchers largely agree about the necessity of introducing quality control in the adult education process, and in recent years, much progress has been made to develop a framework for the evaluation of adult educators.
\end{abstract}

Keywords: adult education, adult educators evaluation, lifelong learning in Latvia, Latvian approach to adult education evaluation

\section{Introduction}

Change permeates every area of our globalised society. As a result, workers require a continuous updating of knowledge and skill sets in order to remain competitive. In this context, the importance of adult learning has increased, and, in recent decades, adult education has become a central focus for economic development.

Accordingly, the quality assessment of the adult education process is a crucial issue, and often, is closely related to the certification of the newly acquired skills.

Adult education, however, is a very wide area which encompasses different scopes, pertaining not only to the world of work, but also to peoples' physical, social, and mental well-being throughout life (active ageing), as well as to the education of people with special needs (prisoners, adult migrants, refugees, the disabled, etc.).

Adult education, continuing education, and lifelong learning are frequently used as synonyms and do not refer to a clearly delimited area, although they are actually connected to different contexts, involve different kinds of people, and respond to different societal priorities.

This can be seen if one compares the practices of adult education in different European countries, and it

Gilberto Marzano, Dr., head of laboratory of pedagogical technologies, Research Institute for Regional Studies, Rezekne University of Applied Sciences.

Velta Lubkina, Ph.D., director, Research Institute for Regional Studies, Rezekne University of Applied Sciences.

Svetlana Usca, Ph.D., researcher, Research Institute for Regional Studies, Rezekne University of Applied Sciences.

Tamara Pigozne, Ph.D., researcher, Department of Pedagogy, University of Latvia. 
becomes more evident if one tackles the question of how adult education is evaluated. In fact, although there is a general agreement on the importance of evaluating education and educators, some problems of interpretation may arise. We encountered these problems within Evaluation for the Professional Development of Adult Education Staff (EduEval) ${ }^{1}$, a project funded by the European Union (EU) focusing on the evaluation of adult education (Marzano, Lubkina, \& Usca, 2014a; 2014b). The problems were due not only to the different approaches to education evaluation, but above all to the different meanings attributed by some project partners to the notion of "educator" itself, and consequently, to the way in which they should be evaluated.

This article reports on the adult education process in Latvia, focusing on the evaluation of adult educators in that country.

However, the difficulties encountered in the EduEval project suggest the need to clarify, in a preliminarily phase, some basic concepts.

\section{Adult Education}

Defining adult education is a useless endeavour, since it encompasses a wide range of educational purposes. The boundaries of adult education are really extensive and difficult to delimit. To start with, the very notion of "adult" is a socio-cultural construction, like the notion of "senior", and depends on a particular society in a particular time (Merriam \& Brockett, 2011).

In the EU context, an adult is pragmatically defined as "Any person aged 16 years or older who has left the initial education and training system", since 16 is the legal age of majority in some EU countries (Brooks \& Burton, 2008). Accordingly, adult education would cover the age range 16 to 60, 64, or 65 .

In the Final Report for: Study on European Terminology in Adult Learning for a Common Language and Common Understanding and Monitoring of the Sector (National Research and Development Centre for Adult Literacy and Numeracy, 2010, p. 6), adult learning is defined as "the entire range of formal, non-formal, and informal learning activities which are undertaken by adults after a break since leaving initial education and training, and which results in the acquisition of new knowledge and skills". This is a pragmatic definition, which includes university-level or higher education undertaken after a break.

Formal, non-formal, and informal learning activities can be summarised as follows (Brooks \& Burton, 2008):

1. Formal learning: Learning that occurs within an organised and structured environment (e.g., in an education or training institution or on the job), and is explicitly designated as learning (in terms of objectives, time, or resources). Formal learning is intentional from the learner's point of view. It typically leads to validation and certification.

2. Non-formal learning: Learning which is embedded in planned activities not explicitly designated as learning (in terms of learning objectives, learning time, or learning support). Non-formal learning is intentional from the learner's point of view.

3. Informal learning: Learning that results from everyday activities related to work, family, or leisure. It is not organised or structured in terms of objectives, time, or learning support. Informal learning is, in most cases, unintentional from the learner's perspective.

In adult education, there are two principal types of educators (often addressed as teacher educators):

1. Teacher: This is a person who is acknowledged as having the status of a teacher of adult learners

\footnotetext{
${ }^{1}$ For more information, please visit http://www.edueval.eu/.
} 
according to the legislation and/or practice of a given country;

2. Trainer: This is a person who works with adult learners to impart practical knowledge or skills, and whose expertise has been acquired through experience and not necessarily through formal qualifications.

However, those who study the theory and practice of education (educationist) and administrators of education are also considered as educators.

Moreover, there is a specific figure of educator, the social educator (or social pedagogue), who is very different to a teacher educator ${ }^{2}$. A social educator is a reflective, professional practitioner who acts in the field of social education.

Social education can be defined as:

The theory about how psychological, social and material conditions and various value orientations encourage or prevent the general development and growth, life quality and welfare of the individual or the group. A fundamental element in social educational work is to facilitate integration and prevent marginalization and social exclusion. This is done in a process of social interaction in order to support and help exposed individuals and groups at risk so that they can develop their own resources in a changing society. (International Association of Social Educators, 2010)

In Italy, there is a particular figure of social educator, the educatore professionale, who is recognized by the Italian Ministry of Health. The training for working in the profession of educatore professionale is handled by medical higher educational institutions. Italy is the only country in Europe where social educators are labeled as health professionals.

Unfortunately, in Italy, the single term "educator" is used indiscriminately to designate those who act in the learning/teaching field (teaching educators) as well as those who act in the social education sector (social educators, social pedagogues, and educatori professionali), omitting the specification teaching and social. This caused confusion during the EduEval project, especially when the issue of the evaluation of adult educators was addressed.

\section{Adult Education Evaluation}

Evaluation is a complex process that applies to a variety of contexts. It can be used to support decision-making, and at the same time, to test the effectiveness of national and international programs in different fields, education included (Mertens, 2014).

If we define adult education as any activity that is concerned with the learning of adults, then the evaluation of adult education appears in all its intrinsic complexity.

Adult education has a place everywhere: in the workplace, in the community, on the Internet, in hospitals, cultural centres, centres for migrants, churches, prisons, libraries, and universities. The activities related to adult education include (Nuissl, 2009):
(a) Teaching;
(b) Management;
(c) Counseling and guidance;
(d) Media;
(e) Program planning;
(f) Support.

\footnotetext{
${ }^{2}$ Recently, a new figure of educator emerged: the lean educator, a person who trains on seeing and managing "the way work is done in a manner that allows you to identify and eliminate waste" (B. Ziskovsky \& J. Ziskovsky, 2007).
} 
Counseling and guidance are activities that are especially concerned with supporting learners in their search for appropriate educational offers, analyzing individual learning needs, overcoming learning problems, and evaluating learning achievements. Media is related to the necessity of interacting with multimedia materials, making searches on the Internet, and the use of new communication technologies.

As a result, the evaluation of adult educators implies the study not only of the models of evaluation, but, above all, the contextualization of the process as well, since the field of application covers a very differentiated spectrum of teaching/learning activities and related competencies, depending on the purpose, situation, content, modality, type of learner, and so on.

Notably, an actual adult education evaluation process engages multifarious objectives, such as obtaining feedback about the quality of an educational program, receiving information for planning educational activities, and assessing the merits and detriments of learners and educators.

Considering the specific experience of the EduEval project and the dissonant opinions of some partners, it is worthwhile observing here that not everyone who is engaged in making evaluations can be defined as being an evaluator, per se. A supervisor who makes evaluations and takes decisions is not an evaluator; he/she remains a person whose job is to oversee everyone else in the work. Evaluating alternatives against selected criteria is one step of the decision-making process, but a decision-maker cannot be confused with an evaluator. Accordingly, a social workers' supervisor can never be deemed to be a sort of adult educators' evaluator, and the idea that supervision can be considered "as one of the possible forms of qualitative evaluation in the field of work with adult educators" (Riva \& Ratsika, 2015) does not make sense.

The above clarifications and points duly noted, in the following paragraphs, we report on the observations resulting from our research in Latvia.

\section{Adult Education in Latvia}

The Education Law (1998) represented the first organic program launched in Latvia aimed at modernizing the national educational system. It was specifically concerned with the development of adult formal and non-formal education, although the concept of lifelong learning became more topical after Latvia joined the EU in 2004.

In the Lifelong Learning Policy 2007-2013 of the Latvian Ministry of Education and Science, lifelong learning and adult education were closely linked, "Adult education: formal, non-formal education and everyday learning that ensures personal development, social integration, and civil participation and competitiveness in labor market during the whole life" (Latvian Ministry of Education and Science, 2007).

Arrangements for the provision of adult formal education are also established by the Vocational Education Law, Higher Education Institutions Law, and other national statutes and regulations.

Results of the Adult Education Survey, carried out in 2007 by the Central Statistical Bureau of Latvia, were used to develop the first new adult education policies.

At present, many types of further education and training are offered to people after graduation; the majority of these are upper secondary vocational education courses (lasting 2-3 years) and training programs, which generally focus on mastering professional skills and knowledge in line with the requirements of the learners' qualification level. The training process and the assessment of achievement for both vocational secondary education and training programs are structured in a similar manner.

The Country Report on the Action Plan on Adult Learning: Latvia (European Commission, 2011) described a situation that is still evolving, although the overall strategic objectives remain the same. They can 
be summarized in two main points:

1. To ensure the availability of lifelong learning for inhabitants regardless of their age, gender, previous education, place of living, level of income, ethnic identity, social status, or functional disorders;

2. To create a qualitative education offer for adults that provides for sustainable competencies necessary for work, civil participation, and personal growth, and to promote the creation of a democratic society and a competitive knowledge economy based on high skill levels.

More recently, important changes are unfolding. These changes relate particularly to the wide diffusion of digital technologies, since the rapid modernization of services is imposing the requirement for new competences and skills.

Many universities have introduced distance learning programs and facilities; e-learning is regularly adopted by all Latvian higher education institutions.

The awareness of the strategic role that education has in facing the new challenging social changes has accelerated a global movement towards the quality assessment of educational activities.

Currently, in Latvia, there are 25 general education evening schools and a wide range of non-formal adult education opportunities provided by the state, local governments, and private education institutions (with an emphasis on up-skilling and re-skilling programs).

According to the previously mentioned Education Law, an education institution is able to provide adult non-formal education programs without holding a license, whereas, conversely, other institutions (e.g., private institutions) require a license issued by local authorities. State schools can be used for adult education activities through an agreement between the school administration and local authorities. Many adult education programs are offered by local institutions; there are several adult training centres established by municipalities at regional and local level. The University of Latvia has one of the few doctoral schools of lifelong learning in the world, whilst a Lifelong Learning Centre (LLL Centre) was opened at Vidzeme University of Applied Sciences in March 2007. The LLL Centre offers teacher continuing education, foreign language courses (for English, German, and French), Latvian language courses for ethnic minorities, computer classes for adults, modular tailor-made courses for the unemployed and job-seekers, and preparatory courses for secondary school graduates for centralized examinations in certain subjects (in English, Latvian, and mathematics).

The latest information available on adult education is the Adult Education Survey compiled by the Central Statistical Bureau of Latvia in 2011. It showed that almost one-third of adults (32.4\%) aged 25-64 were participating in formal and/or non-formal education.

\section{Latvian Approach to Adult Education}

Adult education in Latvia has long and stable traditions. It is primarily aimed at providing evening courses for working adults who have not completed primary or secondary education.

In Latvia, as in most Eastern Europe countries, adult education is very closely connected to societal aspects and to the business sector.

In 2007, the position of adult education was depicted as follows:

Different types of further education and training are offered to persons after graduating from general upper secondary or 2-3 year vocational education and training programs. These programs are focused on mastering professional skills and knowledge in line with the requirements of the respective qualification level. The training process and assessment of achievements are organized in a similar manner as in vocational secondary education and training programs. (State 
Education and Development Agency, 2007)

The economic crisis, however, has led to a reduction in the level of state funding for the adult education sector. Since 2007, the implementation of the lifelong learning strategy enforced by the national legislation has principally been sustained by the European Social Fund and, in part, by private investment.

However, the research into adult education does not only focus on the labor market and the need for new skills. The theoretical work into adult education has been large-scale and intensive. Great attention has been directed on the identification of different target groups, their educational needs, and the barriers existing to both formal and non-formal education. Four principal target groups have been identified:

(a) Individuals with low educational attainment (in 2008, 22.8\% of all jobseekers had only achieved the basic level of education);

(b) Adults re-entering general education;

(c) Pre-pension and pension-aged people;

(d) People with functional disorders.

In the 1990s, after gaining independence from the Soviet regime, access to Anglo-American and European educational theories became immediately available, rapidly countering the strong influence of the Soviet approach in the pedagogical field.

Nowadays, the development policy for Latvian adult education has been designed according to the guidelines set by the basic European policy planning documents, such as the Lisbon Strategy, the Bologna Process, and the European Commission Memorandum on Lifelong Learning.

In recent years, research on the quality of adult education as a part of the educational system has been undertaken, focusing both on the criteria for quality measurement and the quality evaluation process.

The analysis of current Latvian literature shows that there are two different perspectives on adult education, depending on the persons involved in the educational process: Educators are more interested in evaluation and emotional issues, as well as on methodology (e.g., participatory interactions or holistic approaches), whilst workers are almost entirely concerned with the certification of acquired skills.

In the last few years, Latvian researchers have actively participated in three European projects concerning the evaluation of adult education: Agade, Vinepack, and Capival. These projects analyzed both the personal and the professional dimensions of educators, providing the base for the new Latvian approach to adult education. This new approach recognizes the topicality of the evaluation process, and combines the need for a quality-based educational development with the need to offer adult learners with competences, skills, and certifications that are relevant to their work activity. The quality process foresees three phases: self-evaluation, peer evaluation, and joint evaluation. Self-evaluation consists of a reflective analysis of competence; external evaluation is the monitoring and evaluation of competence according to objective checklists and tests; and consolidation refers to the portfolio of consolidated outcomes.

\section{Latvian Adult Learners}

In 2011, the Central Statistical Bureau of Latvia conducted its second Adult Education Survey in order to obtain information on the progress of the lifelong learning strategy's implementation ${ }^{3}$. The same survey was

\footnotetext{
${ }^{3}$ Survey was conducted in all EU member states in compliance with the methodology developed by the Statistical Office of the EU (Eurostat). Within the framework of the survey, population aged 25-64 was surveyed within the whole territory of Latvia-totally 5,048 persons (Central Statistical Bureau of Latvia, 2013; 2014).
} 
carried out in all EU member states. The resulting data showed that almost one-third (32.4\%) of Latvian adults aged 25-64 were participating in some type of formal and/or non-formal education. Females participated more actively (37.4\%) compared to males (26.9\%). Those aged 25-34 were the group with the most active learners (38.0\%). Employed people with higher education participated most frequently in education compared to those without, with $54.3 \%$ to $40.3 \%$ respectively, demonstrating the importance, especially for working people, of acquiring new skills in a rapidly changing society. This observation was confirmed by the characteristics of adult learners: Overall $4.3 \%$ of the population aged 25-64 participated in formal education activities, but employed people more frequently participated in learning activities $(83.5 \%)$, followed by individuals aged 25-34 (55.4\%), and those with higher education (56.6\%).

Table 1 shows the amount paid by participants for adult education.

Table 1

Average Costs Spent by Participants on Adult Education by Gender, Age, Level of Education, and Labor Status (2011) (in Euro)

\begin{tabular}{|c|c|c|c|c|}
\hline & & Formal and/or non-formal education & Formal education & Non-formal education \\
\hline & Total & 168 & 761 & 74 \\
\hline \multirow{2}{*}{ Gender } & Male & 181 & 766 & 74 \\
\hline & Female & 159 & 758 & 74 \\
\hline \multirow{3}{*}{ Age } & $25-34$ years & 299 & 905 & 85 \\
\hline & $35-54$ years & 114 & 620 & 74 \\
\hline & $55-64$ years & 46 & 73 & 46 \\
\hline \multirow{3}{*}{$\begin{array}{l}\text { Level of } \\
\text { education }\end{array}$} & Higher education & 186 & 807 & 87 \\
\hline & Secondary education & 151 & 760 & 57 \\
\hline & $\begin{array}{l}\text { Below secondary or } \\
\text { non-formal education }\end{array}$ & 105 & 289 & 75 \\
\hline \multirow{3}{*}{ Labor status } & Employed & 168 & 817 & 65 \\
\hline & Unemployed & 98 & 508 & 37 \\
\hline & Inactive & 282 & 458 & 279 \\
\hline
\end{tabular}

The survey also revealed that non-formal education plays a significant role in lifelong learning (with $30 \%$ of the 25-64 age group participating in non-formal educational activities). Respondents answered to the question "What were the main reasons you participated in education activity?" in this way: $95.3 \%$, to acquire knowledge useful in everyday life; $86.1 \%$, for further career improvement, and $68.0 \%$, to obtain a certificate/diploma ${ }^{4}$ (see Table 2). It is important to note that adult participation in non-formal educational activities was overwhelmingly work-related, and was, in fact, the key reason given by $77.3 \%$ of respondents.

A research study conducted on a sample of 111 Latgalian $^{5}$ seniors (January-June, 2012) confirmed the strong interest of people aged 60-64 in adult education, since they were "young" seniors, and many of them were still economically active (Usca, Lubkina, \& Marzano, 2013).

However, from all the available data, it emerged that a large part of the Latvian population would have liked to participate in educational activities, but could not, principally due to the costs involved. Half of the respondents $(53.3 \%)$ complained that they could not afford the cost of training. Other barriers were related to work schedules $(35.0 \%)$ and to the lack of time owing to family responsibilities $(30.8 \%)$.

\footnotetext{
${ }^{4}$ A previous comparative survey conducted on EU countries showed that, in Latvia, over $30 \%$ of the population participated in education activity to obtain certificates (Boateng, 2009).

${ }^{5}$ Latgale is one of the four Latvian regions.
} 
Table 2

Reasons of Participation in Non-formal Adult Education by Gender, Age, and Level of Education (2011) (Percent)

\begin{tabular}{|c|c|c|c|c|c|c|c|c|c|}
\hline & \multicolumn{3}{|c|}{ Gender } & \multicolumn{3}{|c|}{ Age } & \multicolumn{3}{|c|}{ Level of education } \\
\hline & Total & Male & Female & $\begin{array}{l}25-34 \\
\text { years }\end{array}$ & $\begin{array}{l}35-54 \\
\text { years }\end{array}$ & $\begin{array}{l}55-64 \\
\text { years }\end{array}$ & $\begin{array}{l}\text { Higher } \\
\text { education }\end{array}$ & $\begin{array}{l}\text { Secondary } \\
\text { education }\end{array}$ & $\begin{array}{l}\text { Below secondary or } \\
\text { non-formal education }\end{array}$ \\
\hline $\begin{array}{l}\text { To do job better and/or } \\
\text { improve career prospects }\end{array}$ & 86.1 & 86.4 & 85.9 & 87.2 & 86.8 & 80.6 & 90.0 & 82.5 & 71.7 \\
\hline $\begin{array}{l}\text { To get knowledge/skills } \\
\text { useful in everyday life }\end{array}$ & 95.3 & 94.3 & 95.7 & 96.7 & 95.2 & 92.6 & 96.6 & 93.9 & 91.7 \\
\hline $\begin{array}{l}\text { To increase knowledge/skills } \\
\text { on an interesting subject }\end{array}$ & 91.6 & 90.5 & 92.2 & 92.2 & 91.4 & 91.0 & 94.9 & 87.7 & 88.3 \\
\hline To obtain certificate & 68.0 & 65.5 & 69.6 & 66.0 & 69.3 & 67.2 & 67.4 & 68.5 & 71.1 \\
\hline Obliged to participate & 48.9 & 55.5 & 44.7 & 47.2 & 49.7 & 49.3 & 50.0 & 48.3 & 40.2 \\
\hline To be less likely to lose job & 52.5 & 55.5 & 50.7 & 51.9 & 52.8 & 52.9 & 54.0 & 51.5 & 42.7 \\
\hline $\begin{array}{l}\text { To meet new people or just } \\
\text { for fun }\end{array}$ & 58.9 & 52.8 & 62.7 & 55.9 & 60.8 & 57.7 & 61.7 & 56.4 & 47.6 \\
\hline $\begin{array}{l}\text { To increase possibilities of } \\
\text { getting a job or changing a } \\
\text { job/profession }\end{array}$ & 45.4 & 45.2 & 45.6 & 53.1 & 43.2 & 38.5 & 42.0 & 45.8 & 59.7 \\
\hline To start own business & 11.9 & 12.3 & 11.6 & 16.2 & 10.6 & 8.2 & 11.4 & 12.3 & 13.9 \\
\hline Other reasons & 0.0 & - & 0.1 & 0.2 & - & - & 0.1 & - & - \\
\hline
\end{tabular}

Note. Source: Adapted from Central Statistical Bureau of Latvia (2013).

\section{Outcomes From the EduEval Research in Latvia}

In Europe, several significant projects have been developed in the field of adult education over the last decade (see Figure 1). EduEval is one of them. This is an EU-funded project that started in 2014. The principal focus of the EduEval project is to gain an understanding of the quality process in adult education, exploring the issue of the evaluation of adult educators through the comparison of theoretical approaches and practices existing in various European countries (Latvia, Poland, Italy, Spain, and Greece).

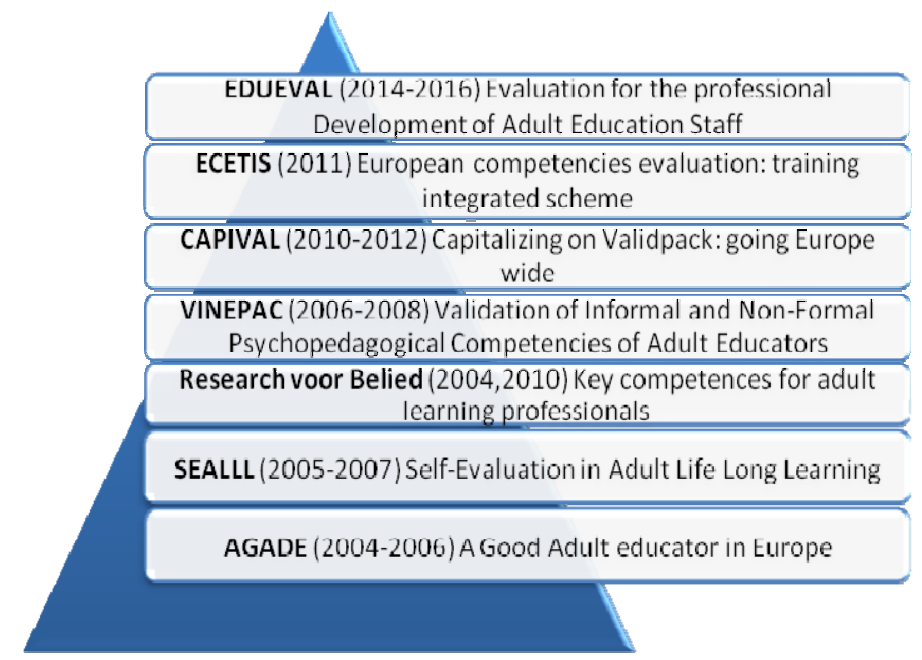

Figure 1. Projects implemented in Europe in the field of adult education (Pigozne, Usca, Lubkina, \& Marzano, 2015).

In Latvia, the EduEval investigative methodology was based on the review of current literature, analysis of statistic data and official documents, Web analysis, a sampling using semi-structured interviews, and the 
observations of 20 educators who were participating in a course on adult education evaluation.

\section{Desk Research}

The research showed that the evaluation of adult educators in Latvia focuses on two principal dimensions: (a) educators' competence and personality; and (b) teaching development. The first factor is related to the need to provide validation and certification of adult learning staff. The second is aimed at aiding teacher educators in their personal growth, trying to support them in their own development.

Competence-based models are currently designed and experimented for the assessment and validation of competences of adult educators (Maslo, Surikova, Karttunen, \& Aarna, 2012).

Many researchers are influenced by the modern pedagogical paradigm of process-oriented evaluation. It helps to distinguish the different components of the evaluation process (Jaspers, 2003; Nagao, 2006; Jääger \& Irons, 2006; Mulder, 2012; El-Kafafi, 2013), and foresees a more active participation of stakeholders (Smith, 2005), aimed at ensuring the sustainability of the evaluation process (Hashimoto, Pillay, \& Hudson, 2010; Knowles, Holton III, \& Swanson, 2014).

In the last few years, the Validpack instrument is showing an increasing success in the evaluation of the psycho-pedagogical competences acquired by adult educators in the non-formal and informal learning context (Rutka, Briede, Surikova, \& Latkovska, 2012). This instrument is organized into three main steps of validation: self-evaluation, external evaluation, and consolidation (Duvekot \& Geerts, 2012). The first step has been the most tested.

From our research, it emerged that in non-formal education, adult educators are very often domain experts or persons who own specific skills and knowledge, but who lack any pedagogical background.

The Internet analysis showed that courses are sometimes part of a personnel selection program, or are frequently used to train staff on new information technology tools or on new regulations (security, safety, and so on).

In Latvia, a figure for adult education evaluation does not exist, although the topic of adult education evaluation and validation is considered to be very important, both by educators and governmental authorities. This is a serious problem, since the lack of a clearly defined competence for professional education evaluators invalidates the application of the evaluation process.

\section{Interviews}

This desk research has been integrated with 16 semi-structured interviews. The interviews were designed to elicit both opinions and suggestions from a small sample of selected stakeholders involved in adult educators' evaluation: five adult education policy-makers and 11 adult education policy implementers.

Although the number of respondents was small, the interview contents have been coded and processed using the AQUAD 6 program. To determine the relationship between the groups of respondents, the Chi-Square test was used, whilst determining correlation was done through the application of Kendall's tau- $b$ correlation analysis. The data analysis results are reported in an article by Pigozne and Usca (2015).

In this paper, we comment on the interview results in the light of the desk research outcomes.

The interviews confirmed that adult education is seen as a means to achieve new skills and competences.

Respondents identified three overlapping objectives of adult education:

1. To give people the opportunity of learning (5 respondents);

2. To satisfy individual education needs (10 respondents); 
3. To improve personal knowledge (12 respondents).

Many respondents expressed the opinion that evaluation should be carried out through "accredited institutions" that "should assess the level of knowledge and expertise/capacity of educators in the long term".

Respondents also recognized the importance of frequent evaluations conducted both internally and externally. They believed that "An internal quality assurance is important to monitor the activities, whereas an external assessment (national and international) should be used to verify whether the internal quality is compliant with national and international standards". External evaluation should be performed by a special committee, composed of public and private professionals, as well as of international experts. In regard to evaluation, respondents indicated two principal educational needs: (a) professional skill improvement; and (b) personal knowledge improvement.

However, they also admit that "There are cases in which competence is not enough" and that "Training is important to improve personal knowledge and quality of life".

The lack of a unified model of evaluation is considered a weak aspect about adult education.

It is very interesting that some respondents' ideal solution to the evaluation issue is a holistic model, albeit one based on objective criteria in order to reduce the risks of subjectivity. In fact, all respondents were persuaded that "Much of the adult education market and the educators mobility depend on a common European evaluation system" and that "If there isn't a common objective evaluation system, assessment will hardly produce practical benefits".

Respondents pointed out that to avoid subjective evaluations, assessment was often based on formal compliance with the established procedures for education programs, "but despite compliance with procedure, methods and skills might not be appropriate to achieve the training objectives". In addition, it would be very important that "Educators learn how to perform their own evaluations".

Respondents recognized that adult education varied depending on students' composition and teachers' professionalism. There is more attention on students' needs, and more specialization is required from teachers. The interviews showed a certain correlation between professional skills and educational objectives. Fifteen respondents indicated that educators should be "persons with specific qualifications and experience" and that a "specialist or academic level" might be necessary, depending on the objectives to be reached.

The majority of the respondents admitted that, in general, the evaluation of adult education staff is a practice "that improves the quality of learning" and that it "should measure the knowledge and skills acquired by learners". Assessment was also considered to be a means for guiding the training activities. However, three respondents critically argued that the meaning of the evaluator of adult education staff was not at all clear.

Finally, from the interviews, we obtained evidence about the criteria, indicators, and methods used or suggested by the respondents for the evaluation of adult education (see Table 3).

Table 3

Indicators and Methods Used in Adult Education Evaluation

\begin{tabular}{|l|l|l|}
\hline Criteria & Indicators & Methods \\
\hline Contents quality & $\begin{array}{l}\text { Educational programs analysis; } \\
\text { Theory-practice ratio; } \\
\text { Relevance of material. }\end{array}$ & $\begin{array}{l}\text { Program's content analysis; } \\
\text { Observation; } \\
\text { Student achievement discussion. }\end{array}$ \\
\hline
\end{tabular}




\section{Observation}

A training course concerning adult education evaluation was performed on April 2015, within the scope of the EduEval project. Twenty adult education practitioners participated in this course, giving us the possibility to gauge their attitudes towards the evaluation of educators.

From this participation, we detected that practitioners show a great preference for the use of proven approaches. They demonstrated an awareness of the relevance of educator evaluation, and a real interest in the practical aspects of evaluation. On the other hand, many doubts were expressed about evaluation based on learners' personal appreciation; instead course participants underlined the necessity of integrating this feedback with other indicators.

As a result of working together with the training course participants, a preliminary framework for the assessment of adult educators' evaluators has been designed. It is based on three major components (see Figure 2): (a) personal development and professional identity; (b) content and didactics; and (c) support for adult educators.

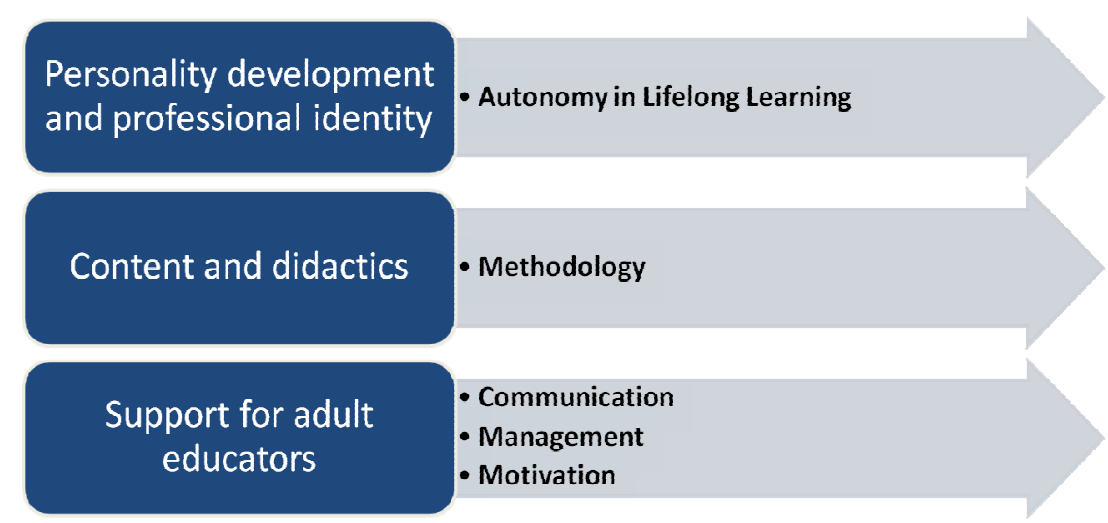

Figure 2. Structure of the assessment of adult educators' evaluators (Pigozne et al., 2015).

\section{Conclusion}

Our research shows that, in Latvia, adult education evaluation is mainly considered as a means to obtain a profitable certification of acquired competencies.

However, both professional adult educators and researchers agree about the importance and indispensability of a measurable quality process (Luka \& Sungsri, 2015). This is in line with EU recommendations for the Latvian educational system, concerning the establishment of an independent accreditation agency and a financing model that rewards quality (European Commission, 2013).

Nevertheless, changes are in motion. The level of confidence in government efforts to introduce quality assessment and validation processes in adult education, especially in non-formal and informal learning, is remarkable. Quality assessment is considered necessary to be able to compete in the global market place (young unemployed people), and for career advancement (employed people).

Finally, the research showed that there are at least two more big challenges related to the professional development of adult educators' evaluation:

1. The motivation of adult educators who are not full-time professionals to update their skills;

2. The creation of policies that orchestrate the various educational needs within the spectrum of lifelong learning sectors. 


\section{References}

Boateng, S. K. (2009). Significant country differences in adult learning. Eurostat: Statistics in Focus, 44, 1-11. Retrieved June 16, 2015, from http://www.uni-mannheim.de/edz/pdf/statinf/09/KS-SF-09-044-EN.pdf

Brooks, G., \& Burton, M. (2008). European adult learning glossary, level 1. National Research and Development Centre for Adult Literacy and Numeracy. Retrieved May 30, 2015, from http://www.pedz.uni-mannheim.de/daten/edz-b/gdbk/10/adult glossary1_en.pdf

Central Statistical Bureau of Latvia. (2013). Main results of adult education survey. Retrieved May 26, 2015, from $\mathrm{http} / / / w w w . c s b . g o v . l v /$ sites/default/files/nr_23_apsekojuma_pieauguso_izglitiba_rezultati_13_00_lv_en_0.pdf

Central Statistical Bureau of Latvia. (2014). Adult education. Retrieved May 26, 2015, from http://www.csb.gov.lv/en/statistikas-temas/metodologija/adult-education-37243.html

Duvekot, R. C., \& Geerts, J. (Eds.). (2012). Handbook for the assessment and validation of pedagogical competences of adult educators. Timisoara: IREA/Brumar.

El-Kafafi, S. (2013). Assessment: The road to quality learning. World Journal of Science, Technology and Sustainable Development, 9(2), 99-107.

European Commission. (2011, March 3). Country report on the action plan on adult learning: Latvia. Retrieved from $\mathrm{https}$ //ec.europa.eu/epale/en/resource-centre/content/country-report-action-plan-adult-learning-latvia

European Commission. (2013). Recommendation for a Council Recommendation on Latvia's 2013 national reform programme and delivering a Council opinion on Latvia's convergence programme for 2012-2016. Retrieved from http://ec.europa.eu/ europe2020/pdf/nd/csr2013_latvia_en.pdf

Hashimoto, K., Pillay, H., \& Hudson, P. (2010). An evaluation framework for sustaining the impact of educational development. Studies in Educational Evaluation, 36(3), 101-110.

International Association of Social Educators. (2010). Working with persons with developmental disabilities: The role of the social educator. Retrieved May 29, 2015, from http://aieji.net/wp-content/uploads/2010/12/Working-with-persons-withdevelopmental-disabilities.pdf

Jääger, T., \& Irons, J. (2006). Towards becoming a good adult educator (Recourse book for adult educators). AGADE Project.

Jaspers, M. (2003). Toetsing, een strategische keuze. Kadernotitie Fontys visie en beleid ten aanzien van toetsing (Assessment, a strategic choice. Notes on the Fontys's assessment vision and policy). Eindhoven: Fontys Hogescholen.

Knowles, M. S., Holton III, E. F., \& Swanson, R. A. (2014). The adult learner: The definitive classic in adult education and human resource development. New York, N.Y.: Routledge.

Latvian Ministry of Education and Science. (2007). Lifelong learning policy 2007-2013. Retrieved June 10, 2015, from http://asemlllhub.org/fileadmin/www.asem.au.dk/LLL_Policies/Latvia_-_Ministry_of_Education_and_Science._Basic_guide lines_of_lifelong_learning_policy_for_2007_-_2013.pdf

Luka, I., \& Sungsri, S. (2015). Lifelong learning strategies and practice in Latvia and Thailand. Policy Futures in Education, 13(4), 529-545.

Marzano, G., Lubkina, V., \& Usca, S. (2014a, May 23-24). Developing practices for adult educators' evaluation. Proceedings of The International Scientific Conference (Vol. II, pp. 162-171).

Marzano, G., Lubkina, V., \& Usca, S. (2014b). Opinions, attitudes and experiences among evaluators of adult educators. Journal of International Scientific Publications, 12, 123-131.

Maslo, I., Surikova, S., Karttunen, A., \& Aarna, O. (2012). Validation of non-formal and informal learning in Latvia, Estonia and Finland: An analysis of the context. Journal of Educational Sciences/Revista de Stiintele Educatiei, 14(2).

Merriam, S. B., \& Brockett, R. G. (2011). The profession and practice of adult education: An introduction. San Francisco, C.A.: John Wiley \& Sons.

Mertens, D. M. (2014). Research and evaluation in education and psychology: Integrating diversity with quantitative, qualitative, and mixed methods. Thousand Oaks, C.A.: Sage Publications.

Mulder, M. (2012). Competence-based education and training. The Journal of Agricultural Education and Extension, 18(3), $305-314$.

Nagao, M. (2006). Challenging times for evaluation of international development assistance. Evaluation Journal of Australia, 6(2), 28-36.

National Research and Development Centre for Adult Literacy and Numeracy. (2010, July 7). Final report for: Study on European terminology in adult learning for a common language and common understanding and monitoring of the sector. Retrieved April 8, 2015, from http://www.pedz.uni-mannheim.de/daten/edz-b/gdbk/10/adultreport_en.pdf 
Nuissl, E. (2009). Profession and professional work in adult education in Europe. Studi Sulla Formazione, 12(1/2), 127-132.

Pigozne, T., \& Usca, S. (2015). Case of Latvia in the evaluation of adult education: Issues and solutions. Paper presented in the Proceedings of the International Scientific Conference (Vol. IV, pp. 165-177).

Pigozne, T., Usca, S., Lubkina, V., \& Marzano, G. (2015). Self-assessment (Report of EduEval project).

Riva, M., \& Ratsika, N. (2015). Supervision as a kind of qualitative evaluation. Society, Integration, Education, 4, 178-189.

Rutka, L., Briede, B., Surikova, S., \& Latkovska, E. (2012). Analysis of the validation instrument of adult educators' competences: The results of the Validpack second testing session in Latvia. Journal of Educational Sciences/Revista de StiinteleEducatiei, 14(2), 42-51.

Smith, H. (2005). Ownership and capacity: Do current donor approaches help or hinder the achievement of international and national targets for education? International Journal of Educational Development, 25(4), 445-455.

State Education and Development Agency. (2007). Latvia: System of education. Retrieved May 29, 2015, from http://www.viaa. gov.lv/files/news/1808/educ_in_latvia.pdf

Timmins, F. (2008). Making sense of nursing portfolios: A guide for students. Maidenhead, U.K.: McGraw-Hill Education.

Usca, S., Lubkina, V. L., \& Marzano, G. (2013). A socio-ecological based feasibility assessment for developing sustainable elderly education programs in the Latgale region (Latvia). Paper presented in the Proceedings of the International Scientific Conference (Vol. III, pp. 213-222).

Ziskovsky, B., \& Ziskovsky, J. (2007). Doing more with less-Going lean in education (A white paper on process improvement in education, Lean Education Enterprises Inc., Shoreview, Minnesota, pp. 1-19). 